University of Nebraska - Lincoln

DigitalCommons@University of Nebraska - Lincoln

Faculty Publications, Classics and Religious

Studies Department

September 2006

German Jewish Printing in the Reformation Era (1530-1633)

Stephen G. Burnett

University of Nebraska - Lincoln, sburnett1@unl.edu

Follow this and additional works at: https://digitalcommons.unl.edu/classicsfacpub

Part of the Classics Commons

Burnett, Stephen G., "German Jewish Printing in the Reformation Era (1530-1633)" (2006). Faculty Publications, Classics and Religious Studies Department. 62.

https://digitalcommons.unl.edu/classicsfacpub/62

This Article is brought to you for free and open access by the Classics and Religious Studies at DigitalCommons@University of Nebraska - Lincoln. It has been accepted for inclusion in Faculty Publications, Classics and Religious Studies Department by an authorized administrator of DigitalCommons@University of Nebraska - Lincoln. 
Published in Jews, Judaism, and the Reformation in Sixteenth-Century Germany, edited by Dean Phillip Bell and Stephen G. Burnett (Leiden \& Boston: Brill, 2006), pp. 503-527. Copyright (C) 2006 BRILL. Used by permission.

\section{German Jewish Printing in the Reformation Era $(1530-1633)^{*}$}

The pioneers of German Jewish printing faced daunting obstacles in their attempts to found and run profitable businesses during a century of religious and political conflict. Yet the Jewish book trade grew and flourished during this period as both the import of Jewish books from Bohemia, Italy, and Poland and the founding of new Jewish presses within the German territories of the Holy Roman Empire demonstrate. While the religious rivalry and conflicts between Catholic and Protestant and between Reformed and Lutheran often complicated the business prospects of these entrepreneurs, the thirst for Hebrew learning among Christians, particularly among Protestants, proved to be a strong argument in favor of allowing Jewish presses to operate. Nevertheless, a combination of restrictive local work and residency policies and the relatively small regional Jewish customer base in Reformation-era Germany doomed many of these presses to failure.

Over the past fifty years most of the scholarly research in the field of German Jewish printing in the Reformation era has fallen into three major categories: bibliographical research, studies of individual printers, and studies of the language and/or text of individual imprints. The most important bibliographical study of German Jewish imprints both in terms of its significance and quality is Joseph Prijs' monumental study of Basel Hebrew printing (1964). ${ }^{1}$ More recently Moshe Rosenfeld's bibliographies of Augs-

* Research for this essay has been funded in part by a Grant-in-Aid from the Research Council of the University of Nebraska-Lincoln, and by generous professional support from the Norman and Bernice Harris Center for Judaic Studies of the University of NebraskaLincoln. I wish to thank Mr. Richard Judd (Bodleian Library, Oxford), Frau Silke Schaeper (Herzog August Bibliothek, Wolfenbüttel), Ms. Dana Tahan (British Library, London), Ms. Heidi Lerner (Stanford University Library) and Frau Nathanja Hüttenmeister (Steinheim Institut, Duisburg) for their considerable help as I prepared this article.

${ }^{1}$ Joseph Prijs, Die Basler Hebräische Drucke (1492-1866), ed. Bernhard Prijs (Olten and Freiburg im Breisgau, 1964), 
burg Hebrew imprints and of early Yiddish printing have provided greater clarity for these two classes of imprints. ${ }^{2}$ Herbert C. Zafren analyzed more technical elements of book production, contributing studies on the typography of Yiddish and an impressive analytical bibliographic study of Hanau imprints. In the latter work he provided not only a rigorous study of his chosen topic, but a word of methodological caution that the true volume of German Jewish printing, as measured by number of titles produced, has yet to be measured accurately. ${ }^{3}$

Some German Jewish printers have also received scholarly attention, especially those active before 1550. Abraham M. Haberman wrote bio-bibliographical studies of the presses of Hayim Schwarz, Paul Fagius, and Israel Zifroni. ${ }^{4}$ Raubenheimer and Weil in their biographies of Fagius and Elijah Levita each devoted some discussion to the Fagius press as well..$^{5}$ I have written an article on Hebrew censorship in Hanau as not only a reflection of local standards of censorship, but as an expression of German imperial law. ${ }^{6}$ The third trend within German Jewish book history, the study of individual texts, lies outside of the scope of this article, but a number of studies especially of Yiddish language works have been published over the last

${ }^{2}$ Moshe N. Rosenfeld, Jewish Printing in Augsburg during the First Half of the Sixteenth Century (London, 1985), and "The Origins of Yiddish Printing," in Origins of the Yiddish Language, Winter Studies in Yiddish Volume 1, ed. Dovid Katz (Oxford, 1987),111-26.

Herbert C. Zafren, "Variety in the Typography of Yiddish: 1535-1635," Hebrew Union College Annual 53 (1983): 137-63, and "A Probe into Hebrew Printing in Hanau in the Seventeenth Century or How Quantifiable is Hebrew Typography," in Studies in Judaica, Karaitica and Islamica Presented to Leon Nemoy on his Eightieth Birthday, ed. Sheldon R. Brunswick (Ramat Gan, 1982), 274-85.

${ }^{4}$ Haberman's essays "The Press of Hayim Shahor [Schwarz], his son and his son-inlaw," "The Press of Paul Fagius and the Books of his Print Shop," and "The Press of Israel Zifroni and his Son Elishema and their Books," [all in Hebrew] have been reprinted in his Studies in the History of Hebrew Printers and Books (Jerusalem, 1978), 103-30, 149-66, and $167-214$.

${ }^{5}$ Richard Raubenheimer, Paul Fagius aus Rheinzabern: Sein Leben und Wirken als Reformator und Gelehrter (Grünstadt, 1957), 25-48, and Gerard E. Weil, Élie Lévita Humaniste et Massorète (1469-1549) (Leiden, 1963), 133-51.

${ }^{6}$ Stephen G. Burnett, "Hebrew Censorship in Hanau: A Mirror of Jewish-Christian Coexistence in Seventeenth Century Germany," in The Expulsion of the Jews: 1492 and After ed. Raymond B. Waddington and Arthur H. Williamson (New York, 1994), 199-222. two decades, most recently Astrid Starck's French translation and commentary on the Maase Buch (1602).?

The portrait that emerges from most existing research is a rather fragmented one of individual printers and books bobbing like corks within the stormy political seas of Reformation-era Germany. The broader political and religious trends that set the conditions under which Jewish printers operated have not been fully considered, although these trends were of critical importance for understanding Jewish presses as businesses. Scholars of German Jewish printing have also tended to focus upon the evidence of the books themselves without seeking to use archival records to flesh out the circumstances in which these books were produced. ${ }^{8}$ An analysis of German Jewish printing within the context of the overall German book trade provides important new insights into both the limitations and possibilities for Jews as producers of cultural products in the Reformation era. HansJörg Künast provided an excellent example of this approach in his study of Jewish printing in Augsburg. By analyzing Jewish printing within the overall context of printing in Augsburg he shed important new light upon the printing career of Hayim Schwarz.

In this study I will consider how the Reformation affected these Jewish printers and their businesses as they attempted to produce and sell Jewish books to a largely Jewish clientele. First I will present capsule histories of the various presses as they operated both before the suppression of the Talmud in 1553, and then afterwards in a new climate of restrictions and press controls. Then I will discuss aspects of the Hebrew printing business, including the creation of printable texts (authors, editors, and censors), customer demand for Jewish books, and how presses financed their activities. And finally, I will consider the theme of Jewish-Christian cooperation in producing Jewish books, since many of these presses were owned by Christians.

${ }^{7}$ Un beau livre d'histoires/Eyn shön Mayse bukh, Traduction du Yiddish, introduction et notes, 2 vols, ed. and trans. Astrid Starck (Basel, 2004).

${ }^{8}$ Zafren warned of the limits of a purely "artifactual approach" in his "Probe into $\mathrm{He}$ brew Printing in Hanau," 283.

${ }^{9}$ Hans-Jörg Künast, "Hebräisch-jüdischer Buchdruck in Schwaben in der ersten Hälfte des 16. Jahrhunderts," in Landjudentum im deutschen Südwesten während der Frühen Neuzeit, ed. Rolf Kiessling and Sabine Ullmann (Berlin, 1999), 277-303. 
German Jewish Printers, 1530-1633

The Reformation had little practical impact upon German Jewish presses before 1553. The printers who produced books in this period were either independent "wandering printers" in the manner of Gershom Soncino or were dependent upon wealthy patrons. Only after 1553 did the papal campaign to suppress the Talmud and the increasingly intrusive imperial printing laws begin to limit where printers could work and what they could print.

Hayim Schwarz (1530-46) had been a printer in Prague during the late 1520s but decided to seek his fortune in Germany after 1527, when the Cohen family was granted an exclusive privilege to print Jewish books in Prague. ${ }^{10}$ He printed books in Oels (1530), Augsburg (1533-40), Ichenhausen (1543-44), and Heddernheim (1546), and ultimately left Germany for Lublin, where he died between 1548 and $1551{ }^{11}$ While in Augsburg Schwarz worked in the print shop of Silvan Otmar, and lived in the home of Bonifacius Wolfhart, a Protestant pastor who also served as the censor of Hebrew books for Augsburg. ${ }^{12}$ Schwarz left Augsburg in 1540 when he and Jewish convert Paul Aemilius were unable to form a partnership. Aemilius worked only a relatively short time as a Jewish printer, but he is important because he was one of the first printers of Judeo-German books. He enjoyed the generous patronage of Johann Albrecht Widmanstetter. ${ }^{13}$

The Hebrew press of Paul Fagius was also relatively short-lived, but it was particularly important for Christian Hebraists since it produced texts and reference books that were critically important to their work. ${ }^{14}$ Fagius was able to hire Elijah Levita to work at the press between December of 1540 and November of $1541 .{ }^{15}$ Levita was not only an experienced printer

${ }^{10}$ Bedrich Nosek, "Katalog mit der Auswahl Hebräischer Drucker Prager Provinenz, Teil I: Drucke der Gersoniden im 16. und 17. Jahrhundert," Judaica Bohemiae 10 (1974): 15.

${ }^{11}$ Marvin J. Heller, Printing the Talmud: A History of the Earliest Printed Editions of the Talmud (Brooklyn, 1992), 328.

12 Künast, "Hebräisch-jüdischer Buchdruck in Schwaben," 283 and 286.

${ }^{13}$ Ibid., 287-91.

${ }^{14}$ Weil, Élie Lévita, 248-85. .

${ }^{15}$ Levita arrived in Isny at the beginning of December, 1540. Gervasius Schuler to Heinrich Bullinger, Memmingen, 14 December 1540, in Heinrich Bullinger Briefwechsel, vol. 10: Briefe des Jahres 1540, ed. Hans Ulrich Bächtold and Rainer Heinrich (Zurich, 2003), 197. Levita had already left Isny by the time Fagius was first called to Strasbourg in November of 1541. Weil, Élie Lévita, 141-43. and corrector, but also a scholar and well-known writer. He reprinted a number of his earlier books in Isny and two books for the very first time: Sefer Meturgeman, an Aramaic dictionary for readers of the Targums, and Sefer Tishbi, a short dictionary of post-biblical Hebrew. Yet after a promising beginning, Fagius was unable to attract enough customers to make the press financially successful. Fagius sold the remainder of his press inventory to Strasbourg bookseller Georg Messerschmidt in 1549. The size of his unsold inventory gives mute testimony to Fagius' shortcomings as an entrepreneur. ${ }^{16}$ In the end Fagius left over 1,000 Reichstaler in debts behind him when he was called to Strasbourg in 1544 to serve as a pastor there and to teach Hebrew at the Strasbourg academy.

The final Jewish printer who worked before 1550 was Samuel Helicz, a member of the first family of Jewish printers in Poland. With his partner Helicz moved to Oels in Silesia in 1534 to found a press there. But a terrible storm severely damaged his press, and scattered his inventory throughout the town and countryside. As Oels minister Ambrosius Moibans described it, ". . . the printed gatherings were blown over all houses, in the streets, throughout the town and outside of the town, even in the fields, torn and hanging from walls and trees." There were so many printed leaves throughout the area that it "looked as if it had snowed." ${ }^{17}$ Samuel was able to print one book in 1536, but in 1537 he converted and was baptized. At the end of his life, after he had left Germany for Constantinople, he returned to Judaism. ${ }^{18}$

${ }^{16}$ The inventory is printed in Weil, Élie Lévita, 149-51.

17 "Dergleichen so haben sie daselbst bey jnen eine fast werckliche drückerei zugericht, darinne sie das Alte testament, so jnn jrer sprache auffs new mit einer glossen und auslegung corrigirt worden, jnn Hebreischer zunge zu drucken furgenommen, welcher exemplar sie ein gantz gemach alle vol gehabt. Dieses eingerissen, die Exemplar und gedruckten sexternen uber alle heuser jn die gassen, der stad, fuer die stad, auch jnn alle weitte feld gefurt eines jnn das ander gemenget, zurissen, an die zeune und beume gehangen, das man des morgens, wie es tag worden, jnn und fur der stad, auch auff dem felde hin und wider geringes umb die stad die selber scarten und gedruckts papir souviel und gantz dicke geligen und funder jnn massen, wie es geschneiet hette." Printed in Gotthard Münch, "Das Oelser Unwetter von 1535 und Moibans Auslegung des 29. Psalms," Jabrbuch für schleische Kirchengeschichte 52 (1973): 55-56.

18 The Hebrew Book: An Historical Survey, ed. Raphael Posner and Israel Ta-Shma (Jerusalem, 1975), 155 
These early Jewish printers all printed their books before the Reformation had begun to have an effect upon the laws regulating printing and the sale of books. Jewish presses had been allowed not only in Germany but also more importantly in various Italian cities, in Prague, and in Cracow. There were no religious or legal limitations upon which books or which kinds of books Jewish printers could produce. Pope Leo X had even granted Daniel Bomberg a privilege to print the Talmud in $1520 .{ }^{19}$ The only legal obligation that Jewish printers had to fulfill under imperial law was that each book be properly censored. ${ }^{20}$ After 1553, the legal environment for Jewish printing changed abruptly.

On 9 September 1553, the Talmud was publicly burned in the Campo de' Fiori in Rome by command of the Roman Inquisition. ${ }^{21}$ The Inquisition justified the destruction of the Talmud by claiming that it was a blasphemous work. Over the next several months other Italian cities confiscated and publicly burned the Talmud following this decree. ${ }^{22}$ The Talmud and its interpretations were added to the Index of Probibited Books in $1559 .{ }^{23}$ The Holy Roman Empire did not officially take up the papal campaign against the Talmud, yet it was a religious and political factor in their policies on printing and the book trade. The Jewish presses in Tiengen and Thannhausen, located in Catholic ruled lands, were both closed down by the authorities, in part because in each case the printers planned to print the Talmud.

If the Holy Roman Empire did not follow papal policy, imperial law increasingly restricted the activities of printers during the second half

19 The privilege itself has not survived but was extensively quoted in Shlomo Simonsohn, The Apostolic See and the Jews, vol. 4, Documents: 1522-1548 (Toronto, 1990), document 1559.

${ }^{20}$ Stephen G. Burnett, "The Regulation of Hebrew Printing in Germany, 1555-1630: Confessional Politics and the Limits of Jewish Toleration," in Infinite Boundaries: Order, Disorder, and Reorder in Early Modern German Culture, ed. Max Reinhart and Thomas Robisheaux (Kirksville, 1998), 329-48.

${ }^{21}$ Fausto Parente, "The Index, The Holy Office, The Condemnation of the Talmud and Publication of Clement VIII's Index," in Church, Censorship and Culture in Early Modern It aly, ed. Gigliola Fragnito and trans. Adrian Belton (Cambridge, 2001), 164.

22 Kenneth R. Stow, "The Burning of the Talmud in 1553, In Light of Sixteenth Century Catholic Attitudes Toward the Talmud," BHR 34 (1972): 435.

${ }^{23}$ Amnon Raz-Krakotzkin, "Censorship, Editing and the Reshaping of Jewish Identity: The Catholic Church and Hebrew Literature in the Sixteenth Century," in Hebraica Veritas, 129. of the sixteenth century. In response to Luther and other Protestant polemicists, the estates of the Empire began in 1521 at the Diet of Worms to create a legal framework for controlling what was printed and sold within Germany. A series of decisions passed by the Diets of Nuremberg (1524), Speyer (1529), and Augsburg (1530) made territorial princes and city magistrates responsible for ensuring that all books produced within their jurisdictions were properly censored and made it clear that all offenders, whether authors or printers, would be punished for violations. ${ }^{24}$ New regulations passed by the Diet of Speyer (1570) and incorporated into the Reichspolizeiordnung of 1577 required that all presses be located in imperial cities, university towns, or residence cities to ensure that all books were properly censored. No clandestine presses (Winckeldruckereien) were to be tolerated. Printers who operated such presses were to be arrested and their books and printing equipment to be seized. All books were to list on their title page the place where they were printed, the name of the author, and the year, to ensure that responsibility for each book was clear. ${ }^{25}$ In 1579, Emperor Maximillian II attempted to extend his authority over book sales at the Frankfurt book fair by creating the Imperial Book Commission. Each of these measures had consequences for German Jewish printing. These new policies, above all those that limited the possible locations for printing businesses, affected German Jewish printers disproportionately because of the highly restrictive residence policies of most German cities.

Eliezer b. Naftali Hirz Treves and Joseph b. Naftali were the first German Jewish printers to experience the consequences of the Talmud prohibition. After they had printed a Judeo-German Psalter in Zurich (1558), they moved their press to Tiengen (Baden). While their only extant works are prayerbooks, they evidently planned to print the Talmud as well. The Suffragen Bishop of Constance was willing to allow the press to operate, but the Swiss Confederation, to which the County of Sulz was subject, was not. On 24 June 1560, representatives of the Confederation learned of the Tiengen press and ordered that the press be closed. Apparently Eliezer and Joseph did not completely give up on their plans. In 1561 unnamed Jewish printers sought permission to print the Talmud in Basel. Hieronymus Froben and Nicolaus Episcopius were willing to print

\footnotetext{
${ }^{24}$ Burnett, "Regulation of Hebrew Printing," 331-32.
}

${ }^{25}$ Ibid., 332. 
the Talmud, but they were forbidden to do so by the city council. ${ }^{26}$ Only twenty years later Ambrosius Froben, son of Hieronymus, would print the Talmud in Basel.

The Jewish press in Thannhausen was the best example of the effectiveness of the new imperial laws concerning clandestine presses. The printers operated openly, and the title pages of their books contained not only Thannhausen as their place of origin and year, but even the names of both the Jewish and Christian printers themselves (in Hebrew). But the press was located in a market town, not in an imperial city, a university town, or a residence city. The imperial authorities in Burgau ordered that the press be closed in June of 1594, and that both the printing equipment and the books be confiscated. One of the correctors, Rabbi Isaac Mazia was arrested, but the other three printers were able to escape from the authorities in time. The time of itinerant and small town German Jewish printers was over.

The final three Jewish presses active between 1550 and 1630 were quite different firms from their predecessors. They were not only much larger firms that produced far more books ( $75 \%$ of all Jewish books produced in Germany before 1650), but they were also far better financed and had close connections with the Frankfurt Jewish community, the second largest in the Holy Roman Empire outside of Prague. ${ }^{27}$ Significantly, they were also located in Protestant cities, whose rulers were aware that some kinds of Jewish printing, particularly Hebrew Bibles, could benefit Protestants as well.

Basel was one of the most important centers of Hebrew printing in Europe, both for Christian Hebrew imprints and for Jewish printing. ${ }^{28}$ The two Basel Hebrew press owners, Ambrosius Froben (1578-84) and Conrad Waldkirch (1593?/98-1612) were both Christians. Neither Froben nor Waldkirch printed Hebrew books at the beginning of his printing career, but when each of them entered the business he printed Hebraica for both Jewish and Christian customers.

26 "Spes erat hic aliqua illum sustentari posse si Talmud Judaicum types excusum esset. Quod conabantur Frobeniami \& Eposcopii nisi a m(a)g(ist)ratu prohibiti essent." Johannes Jung to Heinrich Bullinger, Basel, 15. Juli 1561, ZüSA E II 375, 637r.

${ }^{27}$ Herbert C. Zafren, "Hebrew Printing by and for Frankfurt Jews-to 1800," in Jüdische Kultur in Frankfurt am Main van den Angängen bis zur Gegenwart, ed. Karl E. Grözinger (Wiesbaden, 1997), 231-71.

28 Yeshayahu Vinograd, "The Hebrew Press in the Sixteenth Century (1540-1640)," Alei Sefer 15 (1988-89): 131 [Hebrew].
Ambrosius Froben officially began his career as a Hebrew printer on 2 April 1578, when he signed a contract with a Frankfurt Jew, Simon Günzburg zum Gembs, to print the Talmud. ${ }^{29}$ Froben was to hire the necessary Jewish printers and prepare his press to produce 1,100 copies of the Talmud. He would make six deliveries to Simon zum Gembs during the spring and fall Frankfurt book fairs over the course of the following three years. ${ }^{30}$ Froben was also responsible for negotiating for permission to print the Talmud in Basel and to hire a competent censor who would work in Basel itself. Initially Froben hired Immanuel Tremellius to serve as censor, and later his student Pierre Chevalier of Geneva. ${ }^{31}$

Fausto Parente's recent research in the newly opened Vatican archive of the Congregation of the Index has shed important new light upon the actual Talmud text that Froben was to print. ${ }^{32}$ The contract itself stated that the Talmud text would be from the Venice 1547 Talmud printing of Marcus Antonius Justiniani, as censored by Marco Marino to make it conform to the requirements of the Index. ${ }^{33}$ Parente discovered documents that indicate that the Talmud text had been purged by Marino and his assistants between 1575 and early 1578, under orders from the Congregation of the Index, led by Cardinal Guglielmo Sirleto. The legal basis for Marino's work was the decision of the Council of Trent in 1563 to classify the Talmud among those books that were "prohibited only provisionally until they had been expurgated." 34 Only after the election of Pope Gregory XIII in 1572

${ }^{29}$ Bonaventura Vulcanus, an editor who worked for Froben, reported his plans to print the Talmud in a letter to Rudolf Gwalther in mid 1577. Vulcanius to Gwalther, Basel, after 12 May 1577, in Correspondance de Bonaventura Vulcanius Pendant son Séjour à Cologne, Genève et Bâle, ed. H. de Vries de Heekelingen (The Hague, 1923), 249-52.

${ }^{30}$ Articulirte Clag, Simon Judeus zum Gemms clager contra Hern Ambrosius Frobenium Buchdrucker zu Basel beclagen, Frankfurt/Main, Institut für Stadtgeschichte, Sig. Judicialia F 211, ff. 50a-51a (points 1-4); summarized by Heinrich Pallmann, "Ambrosius Froben von Basel als Drucker des Talmud," Archiv des Deutschen Buchhandels 7 (1882): 47.

${ }^{31}$ Immanuel Tremelius to Theodore Beza, [Sedan, September/October, 1579?], in Correspondance de Théodore de Bèze, ed. Alain Dufour, Béatrice Nicollier, and Reinhard Boden mann, vol. 20 (1579) (Geneva, 1998), 194-99.

${ }^{32}$ Fausto Parente, "The Index, the Holy Office," 171-72.

33 "Articulirte Clag, Simon Judeus zum Gemms ...," Frankfurt/Main, Institut für Stadtgeschichte, Sig. Judicialia F 211, f. 50b, quoted by Pallmann, "Ambrosius Froben," 47.

${ }^{34}$ Parente,"The Index, the Holy Office," 169-73. 
did the Church itself act upon this possibility. Simon zum Gembs apparently learned of the existence of this officially expurgated Talmud text in Italy, probably from Jews in Mantua. In their initial opinion on the Talmud printing, the Basel theological faculty reported that permission had been obtained (presumably by Simon zum Gembs) from the "highest rabbi in Mantua and his officials" to print the Talmud. ${ }^{35}$

Froben's efforts to produce a Talmud that could legally be sold in Catholic lands sparked a determined Catholic campaign aimed at its suppression. Ambrosius Froben and the Basel authorities were pressured by imperial and Swiss authorities no fewer than four times from late 1578 through 1579 in an effort to forbid the printing and sale of the Talmud. The emperor himself sent two letters, one dated 29 November 1578, and the other dated 25 June 1579, to the Basel city council demanding that they order Froben to stop printing the Talmud. ${ }^{36}$ The papal nuncio in Switzerland also met secretly with representatives of Lucerne and Canton Fribourg, and convinced them to make the same demand of the Basel authorities at the meeting of the Swiss Confederation in July of 1579. When Froben visited the Frankfurt book fair in order to deliver an installment of the Talmud printing to Simon zum Gembs, he was summoned by the Imperial Book Commission to answer questions about his activities (10-16 September 1579). ${ }^{37}$

Froben's reaction to these efforts to stop him from printing the Talmud was, paradoxically, to seek direct negotiations with papal authorities. In violation of his contract, Froben had already begun producing a second printing of the Talmud in 1581, with the plan of selling it in Italy himself. ${ }^{38} \mathrm{He}$

35 "Wyl man höre, dass der fürnembste Rabi zu Mantua sampt seiner verordnetten verwilligett habe." Opinion of the Basel Theological Faculty, n. d., Basel SA, Handel und Gewebe JJJ 13, f. 50r. See Ernst Staehelin, "Des Basler Buchdruckers Ambrosius Froben Talmudausgabe und Handel mit Rom," BZGA 30 (1931): 9-10. Shlomo Simonsohn, History of the Jews in the Duchy of Mantua (Jerusalem, 1977), 415-29 discusses the Mantua Jewish community's leading role in negotiating with the Catholic Church for permission to reprint the Talmud between 1563 and 1590, but did not mention a rabbinic authorization for a Basel Talmud printing.

${ }^{36}$ Parente noted that the emperor was pressured to intervene by Cardinal Giulio Antonio Santorio."The Index, The Holy Office," 172 n. 32.

${ }^{37}$ Burnett, "Regulation of Hebrew Printing," 340-41.

${ }^{38}$ Bernhard Prijs and Hermann Süss, "Neues vom Basler Talmuddruck. 2 Nachträge zu J. und B. Prijs, 'Die Basler Hebräischen Drucke' Olten/Freiburg i. Br. 1964," BZGA 82 (1982): 205-12. traveled to Rome in late 1581 to negotiate for permission to sell his new Talmud printing in Italy, and converted to Catholicism on 31 January 1582, in order to better represent his own interests. ${ }^{39}$ On 1 June 1582, Pope Gregory III dashed Froben's hopes by condemning Froben's expurgated edition of the Talmud and ordering canonical punishments for Marco Marino. By Froben's account, Marino had not personally censored the entire Talmud text, but only the "most dangerous parts." Marino's assistants censored the rest of the Talmudic text. ${ }^{40}$ In 1596, Pope Clement VIII would order the wording of the Talmud entry in the Index of Probibited Books changed to prohibit its printing outright. ${ }^{41}$

While Froben lost the opportunity for Talmud sales in Italy, Simon zum Gembs lost much of his investment because of the poor quality of the Talmud tractates that Froben delivered to him. According to the terms of the contract Simon zum Gembs would pay Froben a third of the printing costs at the beginning of the contract, and would then pay off the balance in six payments as Froben delivered printed tractates to the Frankfurt book fair. ${ }^{42}$ After receiving these shipments, Simon discovered the Talmud text had suffered greatly at the hands of the censors, and the individual gatherings had been printed poorly by Froben himself. Froben's assistants had then packed them helter skelter into barrels for shipment, mixing gatherings from different tractates together. After receiving delivery, Simon then had to have the gatherings arranged in their proper order so that he would have complete copies of the Talmud to sell. Therefore Simon zum Gembs revoked his contract with Froben on 21 October 1580, and filed a lawsuit against him in Frankfurt am Main, seeking to receive 9,000 Reichsthaler in damages. ${ }^{43}$ In the end neither Simon nor his heirs and backers were able to conclude their lawsuit because Froben retired from the printing business and never traveled to Frankfurt to stand trial.

Since Froben had acquired enough Hebrew type and he had hired experienced Jewish printers, he produced other Hebrew books for Jewish and Christian customers in addition to the Talmud. In 1580 Froben printed

\footnotetext{
${ }^{39}$ Parente, “The Index, me Holy Office," 173.

${ }^{40}$ Ibid.

${ }^{41}$ Ibid., 193.

42 "Articulirte Clag, Simon Judeus zum Gemms..., Frankfurt/Main, Institut für Stadtgeschichte, Sig. Judicialia F 211, f. 50b, quoted by Pallmann, "Ambrosius Froben," 47.

43 "Articulirte Clag, Simon Judeus zum Gemms ...," Frankfurt/Main, Institut für Stadtgeschichte, Sig. Judicialia F 211, f. 56a.
} 
Marco Marino's Hebrew grammar Gan Eden. Three years later the three sons of Aaron of Pesaro brought his manuscript book Toledot Abaron from Italy to Freiburg im Breisgau to have it printed by Israel Zifroni by the Froben press. ${ }^{44}$

Conrad Waldkirch's experience as a Jewish printer was far more peaceful and profitable than Froben's had been. He was a well-established printer who sent new books to the Frankfurt book fair almost every year between 1583 and his death in 1616 (134 books in Latin and German). In addition, he served as the semi-official printer of Basel University, and printed 780 disputations, posters and other university-related items over the course of his career. ${ }^{45} \mathrm{~A}$ third of his overall book production consisted of Hebrew works, whether for Christians ( 14 books) or for Jews (48 books). Waldkirch's Jewish printers lived in Alschwyl, a village in the Bishopric of Basel, just outside of the city itself: His censor and Hebrew correspondence secretary was Johannes Buxtorf the Elder, professor of Hebrew at Basel University. Waldkirch apparently produced Jewish books under contract. When a Jewish author or patron wished to have a book printed they would pay the production costs and then receive delivery of the entire production run. Waldkirch never listed his Jewish imprints in the Frankfurt book fair catalogues. When Buxtorf mentioned one of Waldkirch's Jewish books, Megillat Sefer (1610), a guide to Jewish letter-writing, he noted that it was available for sale "from Jews in Frankfurt." 6

The final German Jewish press which was active during the Reformation era was the "oriental press" of Hanau. It was founded in 1609 and received an elaborately written concession from Count Philipp Ludwig of Hanau-Münzenburg. The press was financed by Isaac zum Krebs, Abraham zum gulden Schaff, and Samuel zum weissen Rosen, three Frankfurt Jews. The Christian press owner was Hans Jacob Henne, an experienced Christian printer of Hebraica who had previously worked in Basel, and his chief assistant was Seligman Ulma, the Jewish corrector. ${ }^{47}$ During its

${ }^{44}$ Prijs, Drucke, 219-20 and 233-34

45 Production figures for Waldkirch have been drawn from the Basler Drucker Katalog, Basel UB.

${ }^{46}$ Burnett, From Christian Hebraism, 44.

47 Printing Privilege, 1 May 1609, Marburg SA, Best 81 BI 81 no.23, ff. 20a. On the three Jewish partners see Alexander Dietz, Stammbuch der Frankfurter Juden: geschichtliche Mitteilungen über die Frankfurter Judischen Familien von 1349-1849 (Frankfurt am first three to four years the press produced an impressive array of works including three Hebrew Bible printings, one of which (a Hebrew Bible) was intended also for Christian readers, three responsa collections, and Jacob b. Asher's legal compendium Arba’a Turim. After 1614, production slowed to a crawl, usually averaging no more than one to two books a year. ${ }^{48}$

The press had production difficulties for a variety of reasons. There were constantly personnel problems. Seligman Ulma proved to be incapable of correcting very complicated Hebrew books, such as the Bible edition of 1611-14, as Henne complained in a letter of August $1611 .^{49}$ Henne himself died on 17 March 1613. During 1619 the press lay idle, perhaps because two of its experienced Jewish printers, Eliyahu ben Yehuda Ulma and Abraham ben Eliezer Braunschweig, had been hired by Ludwig König to work on the Basel Biblia rabbinica (1618-19).

The three Frankfurt Jews who operated the press had far more serious problems to overcome. On 2 September 1614, they and the rest of the Frankfurt Jewish community were driven from the city by Vincent Fettmilch and his followers. Only two years later were they allowed to return..$^{50}$ The press had already run up debts of 2,000 Reichsthaler by $1616 .{ }^{51} \mathrm{Be}$ tween 1621 and 1632, both Hanau and nearby Frankfurt were embroiled in the Thirty Years War, which further complicated the business prospects of the press. ${ }^{52}$ If they were to print books, could they find enough customers to recoup their costs?

Both the number of books that were produced by the Hanau printers and how long they remained in business have long remained unanswered questions. The final dated archival record related specifically to the press was Walter Keuchen's censorship report on Talmud tractate Hullin, dated

Main, 1907), 458, no.95 (Isaac zum Krebs [Langenbach]), 469, no.56 (Abraham zum gulden Schaff), and 468, no.149 (Samuel zum weissen Rosen [Gelhäuser IV]).

${ }^{48}$ Yeshayahu Vinograd, Thesaurus of the Hebrew Book, vol. 2: Places of Print (Jerusalem, 1993), 162 [Hebrew].

${ }^{49}$ Hans Jacob Henne to Count Philipp Ludwig, n. p., August 1611, Marburg SA Best. 81 BI 81, no.23, ff. 25a-b.

${ }^{50}$ Salo W. Baron, A Social and Religious History of the Jews, vol. XVI: Catholic Restoration and Wars of Religion (New York, 1969), 195-96.

${ }^{51}$ Petition from Abraham zum gulden Schaf and Isaac zum Krebs, July 30, 1616. Marburg SA Best. 81 BI 81, no.23, f. 36a.

${ }^{52}$ See Manfred Agethen, Judenpolitik in der Grafschaft Hanau (forthcoming). 
3 May $1622 .{ }^{53}$ Steinschneider, Vinograd, and other bibliographers have attributed to the Hanau press a number of Jewish books produced between 1622 and 1630 which bore no place of publication, or gave an obviously false one. ${ }^{54}$ Zafren questioned the attribution of these later imprints to Hanau through a rigorous typographical analysis of a selection of Hanau imprints produced between 1610 and $1630 .{ }^{55} \mathrm{He}$ concluded that the only demonstrable connection between the pre-1622 Hanau imprints and the later ones were the names of a few of the same printers that appeared in colophons, and that very little of the type or decorative borders of the early press appeared in the later imprints. ${ }^{56}$

My own analysis of the imprints and of the surviving archival material suggests that the Hanau press continued to operate after 1622 . The sequence of worker names that appear in the colophons of later "Hanau" imprints indicates at least the continuity of the Hanau printing firm, whether located in Hanau or elsewhere. The two most important workers were Eliyahu ben Yehuda Ulma, (named in colophons in imprints dated 1614, 1623, 1625-26, 1628, and 1630) and Abraham ben Yequtiel ha-Cohen Burgau (1610, 1623, 1627-28, and 1630)..$^{57}$ Other workers active in the later press included Mordechai ben Yaakov of Prossnitz (1623 and 1625), and Isaac b. R. Shimon Shmuel Ha-Levi (1623). ${ }^{58}$ The final five "Hanau" imprints (dating from 1627-30), Jacob b. Jekutiel Kofmann, Edut Yaacov (1627), a Siddur (1628), Jacob Levi ben Moses Moelln, Sefer Maharil (1628), Moses b. Israel Isserles, Torat he-Hata (1628), and Eleazar ben Judah of Worms, Sefer ha-Rokeab (1630), all

\section{${ }^{53}$ Marburg SA Best. 81 B81 3/4 no. 5, fol. 79.}

${ }^{54}$ For example, see his entries for the following prayerbooks: Siddur: StCB p. 321/2124, p. 322/2126, 2127, and 2130; Machzor: StCB 378/2474, Selichot: StCB 435/2850. Vinograd, Thesaurus of the Hebrew Book, 2:163, Hanau numbers, 36, 37, 43, and 50; Machzor: 42; Selichot, 44.

55 Zafren, "Probe into Hebrew Printing in Hanau," 273-85. He reiterated his position recently in Zafren, "Hebrew Printing by and for Frankfurt Jews," 235.

${ }^{56}$ Zafren,"Probe into Hebrew Printing in Hanau," 281-82.

${ }^{57}$ Eliyahu ben Yehuda Ulma, see Vinograd, Thesaurus, 2:163, Hanau imprints nos. 15 , 16, 42-44, 47, 48, 51, 53, and 58 (1614-30); Abraham ben Yequtiel ha-Cohen Burgau: Vinograd, Thesaurus, 2:163, Hanau imprints 10,47,48,49, 51, 53, 58, and Bibliography of the Hebrew Book record imprints 184632 (1610) and 306750 (1623)

${ }^{58}$ Mordechai ben Yaakov of Prossnitz, see Vinograd, Thesaurus, 2:163, Hanau imprints 37, 39, 42, 43, and 44 (1623-25) Isaac b. R. Shimon Shmuel Ha-Levi, Vinograd, Thesaurus, 2: 163, Hanau imprints 10, 19 and 36. share a striking title page layout, which is framed by the heads of four cherubim. ${ }^{59}$

The 1628 Siddur was edited by David ben Menahem Cohen, who also edited the "Hanau" printing of the Shulhan 'Aruk (1626-28). The latter work was printed according to the colophon by Eliyahu ben Yehuda Ulma and Abraham ben Yekutiel Burgau. ${ }^{60} \mathrm{R}$. David ben Menahem Cohen had strong connections with Hanau at this point in his career. His father R. Menahem ben David died and was buried there in 1627, as was his sister Gutrut in $1635 .{ }^{61} \mathrm{R}$. David served as Hanau's rabbi from 1638-41, when he was called to Altona. ${ }^{62}$ Eliyahu ben Yehuda and R. David ben Menahem both had ties to Hanau and they collaborated in producing a printing of the Shulhan 'Aruk. Each of their names appeared in one or more imprints with the distinctive four cherubim title page, a decorative element that was presumably owned and used by the same Jewish printing firm. While I agree with Zafren that a systematic analysis of all of these imprints is still a desideratum, and that perhaps some of Steinschneider's "Hanau" imprints were in fact printed elsewhere, I believe that the Jewish press in Hanau of 1610-22 continued to produce books there between 1623 and $1630 .{ }^{63}$

${ }^{59}$ Meir Rafeld and Yosef Tobori noted the identical tide pages of the Siddur, Sefer Mabaril, and Torat he-Hata in their facsimile reprint, Sidur Hanau 388: Mabadurab fasimilit (Ramat Gan, 1994), 35 and 89-90. Through the courtesy of the Special Collections departments of the Marburg UB and Freiburg/Br UB, I received photocopies of the title page of 'Edut Yaacov (1627) from Freiburg UB (Sig. PO 76/1), and of Sefer ha-Roqeab from Marburg UB (Sig. III C 71) which allowed me to make these further connections.

${ }^{60}$ For a description of the book, see Giulio Busi, Libri ebraici a Mantova, Biblioteca Comunale di Mantova, vol. 2: Le edizioni del XVII, VIII e XIX secolo nella biblioteca della Comuta ebraica (Fiesole, 1997), 113.

${ }^{61}$ Memorbuch Hanau, Jerusalem: Jewish National and University Library Ms. Heb 80 3222, entries 14 and 23. I consulted a transcript of it at the Steinheim Institut, Universität Duisburg. I wish to thank Frau Nathanja Hüttenmeister for her geneaological advice on Jews living in Hanau and Frankfurt am Main during this period and for translating portions of the Memorbuch for me.

${ }^{62}$ Leopold Löwenstein, "Das Rabbinat in Hanau, nebst Beiträgen zur Geschichte der Dortigen Juden," Jahrbuch der Jüdisch-Literarischen Gesellschaft 14 (1921): 9.EJ, s. v. "Altona." His son Elia Hanau married Glückel of Hameln's Aunt Ulk, and died there in 1653. See David Simonsen, “Eine Confrontation zwischen Glückel Hameln's Memorien und den alten Hamburger Grabbüchern," MGWJ 49 (1905): 102-03.

${ }^{63}$ A systematic examination of the type used in later (and earlier) Hanau imprints is especially desirable. Moshe Rosenfeld discovered a Jewish calendar dating from 1625-26, which he attributed to the Hanau press on the basis of its Hebrew type. "Ein jüdischen Wandkalendar für das Jahr 5386 (1625-1626)," in Nachrichten der jüdischen Bürger Fürth (1990), 31-32. 


\section{Business Aspects of German Jewish Printing}

To consider the impact of the Reformation upon German Jewish printing we can examine three facets of the business life of these presses: the creation of printable texts, customer demand, and the financing of Jewish printing. Amnon Raz-Krakotzkin has argued forcefully that the significance of the censorship of Jewish books in the early modern period involved far more than the vetting of individual texts for their suitability to print. The nature of printing itself meant that Jewish books were subject to far greater Christian scrutiny than manuscript books had been. This new level of scrutiny resulted not only in self-censorship by authors, and prepublication censorship, sometimes by both rabbinic and Christian authorities, but also in Jewish texts that were "explicitly authorized" for production and sale by Christian authorities. ${ }^{64}$ The process of creating acceptable texts through both Jewish and Christian pre-publication review was central to the success of German Jewish printers in the Reformation era.

Before 1553, German imperial law required only that Jewish printed books be censored, and there is little evidence that even this requirement was enforced. The only extant censor's report dating from before 1553 was written by Bonifacius Wolfhart in Augsburg on a prayerbook printed by Hayim Schwarz. ${ }^{65}$ Schwarz was aware that his books were subject to censorship, and he showed a degree of caution by leaving out some of the words of the Alenu prayer in his 1534 prayerbook, marking their absence with a space. ${ }^{66}$ Paul Fagius' freedom to print Jewish anti-Christian polemical passages indicates that "censorship" before 1553 was very much a matter of the printer's perception of risk. In several of his works for Christian Hebrew students, the Latin version of Liber Fidei (Isny, 1542), and his translation of David Kimhi's commentary on Psalms 1-10 (Constance, 1544), Fagius made available in Latin some rather bracing Jewish rejoinders to Christian claims, including Kimhi's caustic remarks on Ps. 2: 12, which did not appear in the first Bomberg Biblia rabbinica of 1517. Remarkably he was willing to include Kimhi's Response to the Christians in his printing of Kimhi's

${ }^{64}$ Raz-Krakotzkin, “Censorship," 133-34

${ }^{65}$ Künast, "Hebräisch-jüdischer Buchdruck," 286 and n. 32.

${ }^{66}$ Tefillot (Augsburg: Schwarz, 1534), no foliation. Basel UB call no. FA VIII 57. Burnett, From Christian Hebraism, 38 n. 15. The Soncinos had already removed many antiChristian expressions from their prayerbook imprints. Raz-Krakotzkin, “Censorship," 142.
Psalms commentary in 1542 , a commentary that was protected from reprint by an imperial privilege ${ }^{67}$ After the suppression of the Talmud in Italy, such equanimity was no longer possible either for German Jewish printers or for the local authorities.

As a consequence of the Reformation the opportunities for German Jewish printers became more limited, both because of the promulgation of laws restricting where printers could practice their trade, and the papal campaign against the Talmud in Italy. To ensure that Jewish printing could continue, Jewish community authorities instituted their own pre-publication screening of texts. .A rabbinical meeting in Ferrara on 21 June 1554, decreed that no Jewish book could be printed in Italy without the permission of three rabbis. An assembly of German rabbis and community leaders meeting in Frankfurt am Main passed a similar decree in 1582."No Jew in our province shall be permitted to publish any book, new or old, at Basel or any other city in Germany, without permission of the central courts (Batai Aboth Beth Din). If anyone transgresses this law and publishes the books without permission, no man shall purchase the books under the punishment of the ban." ${ }^{68}$ While theoretically binding on German-Jewish printers, the policy was practically speaking difficult to enforce. However, some of the approbations in early Hanau imprints contain wording suggesting that they functioned as statements of permission, allowing works to be printed. ${ }^{69}$

After 1553, the formal requirement of pre-publication censorship was much more stringently enforced in German lands. The Basel authorities in the time of both Ambrosius Froben and later Conrad Waldkirch insisted on proper censorship of any Jewish books produced by these firms. The series of censor's reports preserved for the Hanau Hebrew press, all written between 1610-22, provide uniquely important information on actual standards applied by Christian censors to Jewish texts. Walter Keuchen, the censor, reviewed forty-two potential Jewish imprints, and only twice did he advise the council to withhold permission to print. One prayerbook contained, in Keuchen's opinion, elements of magic and was therefore danger-

67 Sefer Tebillim 'im Pirush Rabi David Kimbi (Isny: Fagius, 1541). See Abraham M. Haberman, “The Printer Paul Fagius," 163.

${ }^{68}$ Eric Zimmer, Jewish Synods in Germany during the Late Middle Ages (1286-1603) (New York, 1978), 83.

${ }^{69}$ Burnett, "Hebrew Printing in Hanau," 214 n. 25. 
ous. The other book, the Vincenzlied, he argued against for political reasons. When the Jews of Frankfurt am Main had returned in triumph with a military escort to their old quarter in Frankfurt on 28 February 1616, after the Fettmilch uprising had been crushed, R. Elhanan Heln had written a festive song in Hebrew and Yiddish to celebrate the event. The Frankfurt Jewish publishers who underwrote the Hanau press sought to have the song printed in Hanau, but their petition was rejected. Hanau was a neighbor of Frankfurt, and the authorities were not willing to stir up political trouble with Frankfurt by allowing its printing. ${ }^{70}$

Keuchen's reports reflect for the most part a good understanding of Jewish literature. He had a clear idea of what Jewish printers might and might not lawfully print. If a book was questionable in some way, Keuchen demanded that the printers not only submit the book for pre-publication censorship, but that each newly printed page proof should also be brought to him, so that he could satisfy himself that no unauthorized changes had been made. He demanded that the printers follow this procedure when they printed two Talmud tractates in 1618 and $1622 .{ }^{71}$

Faced with such pervasive oversight, German Jewish printers frequently followed the path of least resistance and reprinted books that had already been printed (and censored) elsewhere. The Hanau press was actually required to produce only reprinted works in its privilege, although this restriction was later loosened or ignored. ${ }^{72}$ Yet Jewish authors of new works also sought to have their works printed on German Jewish presses. Elijah Levita vainly sought a press in Italy to print his Aramaic dictionary Sefer Meturgeman, even though he had an enviable reputation as a scholar and writer. Only when Paul Fagius invited him to work in Isny did he find a printer. In 1599, Buxtorf told a colleague, "I receive many letters from Jews who live in many different countries, even Poland. But the reason is Waldkirch's press. For the same reason they are always sending me books to have printed." ${ }^{73}$ Prague author Sabbatai Hurwitz had his book Shefa Tal (1612) printed in Hanau rather than Prague.

If Jewish authors were sometimes obliged to seek printers outside of their own countries, German Jewish printers also sought customers in foreign lands as well as in their own regions, because they had to in order to make a

\footnotetext{
70 Ibid. 209-10.

${ }^{71}$ Ibid., 204-08.

${ }^{72}$ Ibid., 207.

${ }^{73}$ Burnett, From Christian Hebraism, 43.
}

profit. Germany was not a major center of Jewish life, and German printers had no large home market to sell to as printers in Italy, Bohemia, and Poland did. The Thannhausen printers, for example, planned to sell their books in Poland and in Siebenburgen. ${ }^{74}$ Ambrosius Froben planned to sell exemplars of the Talmud in Italy, although his contract reserved all sales for Simon zum Gembs, who planned to market them in Germany and Poland.

An analysis of the 186 books produced by German Jewish printers re veals something about Jewish customer demand in the Reformation era ${ }^{75}$ The overall proportions track remarkably well with Baruchson's analysis of the contents of Jewish libraries in late sixteenth century Mantua as a rough reflection of Jewish customer demand there. ${ }^{76}$

\begin{tabular}{|c|c|c|}
\hline Categories & German Imprints & $\begin{array}{c}\text { Baruchson re: } \\
\text { Mantua }\end{array}$ \\
\hline Liturgy & $50=26.9 \%$ & $34.7 \%$ \\
\hline Bible $\&$ Commentaries & $38=20.4 \%$ & $22.2 \%$ \\
\hline Halakah (Jewish Law) & $21=11.3 \%$ & $10.7 \%$ \\
\hline Mishnah/Talmud/Comm. & $16=8.6 \%$ & $3 \%$ \\
\hline Ethics & $15=8.1 \%$ & $6.2 \%$ \\
\hline Grammar, etc. & $13=7 \%$ & $4.2 \%$ \\
\hline Kabbalah & $13=7 \%$ & $2.7 \%$ \\
\hline Midrash/Aggadah & $5=2.7 \%$ & $2.6 \%$ \\
\hline Belle Lettres & $4=2.1 \%$ & $1.4 \%$ \\
\hline Other ${ }^{77}$ & $8=4.3 \%$ & $3.3 \%$ \\
\hline Responsa & $3=1.6 \%$ & $1.6 \%$ \\
\hline
\end{tabular}

${ }^{74}$ Burnett, "Regulation of Hebrew Printing," 336.

${ }^{75} \mathrm{I}$ have created a database of German-Jewish imprints before 1650, which I assembled using Vinograd's listings as a point of departure and then verifying the existence of physical copies of all but three of the books through the use of published library catalogues and online catalogues including the Bibliography of the Hebrew Book for its listing of Hanau imprints. I have defined German "Jewish" imprints as books printed in Hebrew or Judeo-German, with at most a partial Latin title page. I have excluded books with Latin introductions, but have included Moses Abudiente b. Gidhon, Gramatica Hebraica, parte i onde se mosram todas as regra ... (Hamburg: unknown, 1633), a Hebrew grammar written in Portuguese that was clearly intended for Sephardic Jewish customers.

${ }^{76}$ Shifra Baruchson Arbib, La Culture Livresque des Juifs d'Italie a la Fin de la Renaissance, trans. Gabriel Roth (Paris, 2001), 53.

77 Other $=$ Polemics (1), History (3), Calendar (1), Sermons (1), Philosophy (1), Travel (1). 
Prayerbooks were a staple of Jewish printing (26.9\%), yet printings of entire Bibles, parts of Bibles (20.4\%), and works on Jewish law (11.3\%) were also much in demand. Fully $21.5 \%$ of all German Jewish imprints (40 out of 186) were in Judeo-German and were intended primarily for Jewish women, but also as one Basel title page bluntly put it," for men who are like women in not having much knowledge." 78 These production figures alone are not enough to provide an accurate profile of customer tastes and demand among German Jews of the Reformation era, since Jewish books printed in Italy, Bohemia, and Poland were imported, sold, and read by them as well. However, when compared with Baruchson's analysis, these statistics indicate which kinds of books the press owners and financial backers thought were likely to sell most briskly among their likely customers, and their calculations were probably shrewd ones.

To finance their printing activities German Jewish presses employed a variety of different strategies. Baruchson discussed four major methods of finance used by Jewish printers in Italy: self-financing through private capital, renting one's press to another printer, entering a partnership arrangement (which could include one party borrowing money from the other), and seeking subscription purchases to finance a book's printing. ${ }^{79}$ The first three of these methods were used by German Jewish printers as well. Ambrosius Froben invested not only capital from Simon zum Gembs, but also his own wealth in his Jewish press since he produced other Jewish books, as well as several additional runs of Talmud tractates in 1580. The Hanau Hebrew press was a partnership between Hans Jacob Henne, his Jewish assistant Seligman Ulma, and the three Frankfurt underwriters, and all parties were named in the printing privilege. Henne also printed books for other clients, notably the monumental oriental lexicon of Valentin Schindler for Johann Jacob Ruland of Frankfurt. ${ }^{80}$ After Henne's death the Jewish press of Hanau was hired by Solomon Hirsch Aufhausen to print his own book, Yudischer Theriak in $1615 .{ }^{81}$

${ }^{78}$ Chava Weissler, "The Religion of Traditional Ashkenazic Women: Some Methodological Issues," AJS Review 12 ( 1987): 78, quoting Moses b. Enoch Altschuler, Brandspie gel (Basel, 1602).

79 Zipora Baruchson, "Money and Culture: Financing Sources and Methods in the $\mathrm{He}$ brew Printing Shops in Cinquecento Italy," La Bibliofilia 92 (1990): 33.

${ }^{80}$ Valentin Schindler Lexicon Pentaglotton, ed. Engelbert Engels (Hanau: Hans Jacob Henne, 1612).

${ }^{81}$ Burnett, "Hebrew Censorship in Hanau," 208-09.
The two most significant sources of funding and customers for Jewish books in Reformation-era Germany were clearly the Jewish communities in Frankfurt am Main and the Burgau region. The major presses of Basel and Hanau and the smaller Tiengen press all had ties to Frankfurt. When Count Philipp Ludwig of Hanau refused to allow the three Jewish funders of the Hanau press to operate in Hanau unless they moved from Frankfurt to Hanau, they retorted that they could just as easily have books printed in Basel, a point that the count was forced to concede. ${ }^{82}$ The most prominent Burgau funder was Simon zum Gembs of the Günzburg family of Burgau, but the activities of Jewish presses in Augsburg, Ichenhausen, and Thannhausen also suggest financial support from Burgau Jews.

\section{Jewish-Christian Cooperation in Hebrew Printing}

In the regulatory and religious climate of Reformation-era Germany cooperation between Jewish and Christian printers was essential for producing Jewish books. This common effort was frequently hindered by incompetent printers, both Jewish and Christian, conflicting work calendars, and the mistrust of Jewish workers by both Christian printers and the authorities. Normally the incompetent workers in question were Christian typesetters, correctors, or shop assistants. While non-Jewish typesetters could set Hebrew or Yiddish type according to the master copy they were given, they were usually illiterate in these languages and were simply reproducing what they saw. This practice resulted in frequent errors, especially on Saturdays when Jewish correctors refused to work and Christian workers assumed the responsibility. Not infrequently Hebrew books printed in Basel and Hanau contained an apology from the Jewish corrector at the end that blamed the errors on their Christian coworkers. ${ }^{83}$ Christian typesetters also had difficulties reading manuscript master copies. On two occasions Waldkirch had to have manuscripts that had been written in Hebrew cursive transcribed into a more readable Hebrew script so that his typeset-

${ }^{82}$ Marburg SA, Protokolle II (Hanau) A 2 c, Bd. 4/4, f. 467 (16 March 1609), quoted by Manfred Agethen, Judenpolitik.

${ }^{83}$ Abraham Yaari,"Complaints of Proofreaders about Printing by Non-Jews on the Sabbath," in idem, Studies in Hebrew Booklore (Jerusalem, 1958), 172-75 [Hebrew]. 
ters could work from them. ${ }^{84}$ Waldkirch was forced to use Christian rather than Jewish typesetters in part because of the strict limits that the Basel city council placed upon the number of Jewish printers allowed to work in the city. Jewish presses in Prague, Lublin, and Cracow were able to employ Jews both for typesetting and correcting. ${ }^{85}$ Yet Jewish workers were not always capable at their tasks. Hans Jacob Henne quarreled with Seligman Ulma in 1611, when the latter had trouble correcting a Bible imprint because of his poor eyesight. ${ }^{86}$

The differing workweeks of Jews and Christians were perpetually a source of friction between them. Jews could not work on the Sabbath, while Christian press owners such as Froben, Waldkirch, and Henne refused not only to close the press on Saturday, but also to allow work on Sundays. ${ }^{87}$ The Jewish printers of Hanau complained frequently to the authorities about the prohibition on Sunday work. In a petition of 18 October 1611, they vainly sought to have the press moved to the Jewish street in the Hanau Neustadt to facilitate Sunday work. ${ }^{88}$ On 26 January 1618 the princely council received another such petition which they tersely answered "Rejected. [The Jews] should observe our holiday as well." ${ }^{89}$

Yet the friction over workdays arose not only for religious reasons, but also out of the Christian authorities' distrust of Jewish printers. When the Hanau princely council flatly rejected the printer's petition to move the press in 1611, part of their reasoning was that "their wish could result in unbearable difficulties for the government and censor." ${ }^{\prime 0}$ They clearly believed that Jewish printers were perfectly capable of slipping last-minute

${ }^{84}$ Burnett, From Christian Hebraism, 39 and n. !9.

85 Nosek, "Katalog," 18-24.

${ }^{86}$ Hans Jacob Henne to Count Philipp Ludwig, n.p., August 1611, Marburg SA Best. 81 BI 81, no.23, ff. 25a-b. Henne was unable to rid himself of Seligman who worked at the press until at least 1615 when he corrected for the Joseph b. Abraham Gikatilla, Ginat Egoz. Yaari, "Complaints," 175.

${ }^{87}$ Walter Keuchen noted that the rule was sometimes quietly bent to allow Jews to perform some Sunday work. “... pflege ich den Sambstag, was zu corrigieren, allein zu überlesen, welches Sontags von Judischen Setzer corrigieren, und von mir und meinen lectore Montags morgens letzlich überlesen word." Walter Keuchen to Johannes Buxtorf, n.p., January 19, 1618, Basel UB Ms G I 60: 320b.

${ }^{88}$ Marburg SA, Best. 86 no. 29,088, quoted by Agethen, Judenpolitik, n. 419.

${ }^{89}$ Marburg SA, Best II A no. 2c, vol. 9, part 2 (26 January 1618).

${ }^{90}$ Marburg SA, Best. 86 no. 29,088, quoted by Agethen, Judenpolitik, n. 419. changes into the censored texts of the books they had been authorized to print, and that should such changes prove to be embarrassing or indeed blasphemous, the town government would suffer for it. In 1615, Walter Keuchen, the Hebrew censor of Hanau, reported just such a case. He discovered unauthorized changes had been made to the polemical book Yudischer Theriak, and demanded that the council "order [the printers] to stop working and that they be fined for violating the printing concession so that they might be more obedient in the future." 91 Keuchen had worked for years with these printers, and still believed that they were capable of making unauthorized changes whenever his back was turned. The common labor of Jews and Christians in Jewish presses was not an equal partnership in the effort to make a living. The Christian presence served also to protect the reputation of both the authorities and their city from the potentially dangerous consequences of printing Jewish books.

\section{Conclusion}

The German Reformation affected German Jewish presses most directly in the form of new restrictions on printing, and in an awareness among Christian rulers of the potential political and religious dangers that allowing such printing might pose for their domains. The increasingly restrictive press control laws passed by successive German diets were imposed upon all printers, Christian and Jewish, but they affected Jewish printers disproportionately because of the tight restrictions placed upon Jewish residence throughout the cities and territories of the German empire, which predated the Reformation. ${ }^{92}$ Jews could only live where local authorities tolerated them, and could only print in such places as Hanau where they received explicit permission to do so. As a further consequence of residence restrictions Jewish printers frequently had a mixed work force of Jews and non-Jews producing Jewish books, resulting in books riddled with typographical errors. German Jewish presses also had to compete with other

91 "...die arbeit widerzulegen, und sie wegen obgesatzter ubergangner Concessions verschreibung, gebürlich ahnsehen, damit sie hinshüro gehorsamer wörden." Marburg SA Best 81 BI 81 no. 23, fl. 35 a.

92 Jonathan I. Israel, European Jewry in the Age of Mercantilism 1550-1750, 3rd ed. (London, 1998), 6-13 and 18-19. 
Jewish presses in Italy, Poland, and Bohemia, which were allowed to employ a mostly or entirely Jewish work force and which could market their wares to a larger potential Jewish clientele within their own regions.

Official censorship was more a business expense and a source of delays for German Jewish printers than a serious barrier to business. In Protestant-ruled territories, censors had to approve the text for printing and on occasion demanded special procedures to ensure that the text that they had authorized was the text that was printed. Jewish editors and printers had already begun the process of quietly editing prayerbooks and other texts before 1553, and by the early seventeenth century, with the exception of the Talmud, older Jewish books could be printed and reprinted without fear of trouble. ${ }^{93}$ The evidence of the Hanau press suggests that the ground rules of what could be printed were clear enough that most new books were approved with little or no controversy.

More ominous for German Jewish printers was the climate of official suspicion of their activities and fear of the consequences of permitting Jewish printing. The Hanau princely council deliberated anxiously over the propriety of allowing a Jewish press to operate there on 22 February 1609. One councilor, Dr. Philipp Bott, feared that by allowing Jewish printing Hanau would be opening itself up for attack from its Catholic and Lutheran confessional enemies.

If we give the Jews permission to open a press, the Ubiquitarians [Lutherans], Jesuits and others will say 'now we see what we are dealing with' and what Hunnius wrote in Calvin the Judaizer was true. Indeed (our decision) will provoke criticism, disputations, and hatred from every side. ${ }^{94}$

The Basel city council's decision to allow Ambrosius Froben to print the Talmud in Basel resulted in a series of religiously-motivated political attacks from within the Swiss Confederation and from the German emperor in 1578-79. Walther Keuchen's insistence that he review Talmud tractates twice before allowing the Hanau printers to print them between 1618-22, and his wrathful report in 1615 that unauthorized changes had been made to an approved text illustrate official fears that Jews were capable of inserting blasphemous statements into the final printed version of Jewish books.

93 Raz-Krakotzkin, "Censorship," 139-42.

94 Extract Protocols vom 22. Febr. Ao 609, Marburg SA Best. 81 BI 81, no.23, ff. 6b and $5 \mathrm{~b}$.
The climate of political and religious confrontation that pervaded the Reformation era meant that failure to prevent blasphemy from appearing in print would harm the reputation of the town and make it more vulnerable to political attack from confessional opponents.

That Jewish printing was possible at all in such a restrictive legal and religious climate attests to the demand for Jewish books in the Reformation era. The city of Basel was the fifth largest overall producer of Hebrew books (for both Christian and Jewish customers) during the 1590s, an indication of just how strong a demand there was for Hebrew books during this era. Apart from the justly maligned Basel Talmud, Basel Jewish presses also produced such monumental works as Nathan b. Yehiel's talmudic dictionary Sefer ha-Aruk (1599), and an important printing of the Rabbinical Bible (1618-19). The Hanau press produced not only a credible number of early Yiddish imprints, but also several important kabbalistic works. ${ }^{95}$ The golden age of German Jewish printing only began with the end of the Thirty Years War, but the often-embattled Jewish printers of this earlier era left an important mark of their own on both Jewish life and Christian Hebrew learning that should not be forgotten. ${ }^{96}$

\section{Stephen G. Burnett}

University of Nebraska-Lincoln

\footnotetext{
95 Posner and Ta-Shema, Hebrew Book, 101.

96 Menahem Schmelzer, "Hebrew Printing and Publishing in Germany, 1650-1750: On Jewish Book Culture and the Emergence of Early Modern Jewry" LBIYB 33 (1988):
} $369-83$. 